\title{
Distribution and Metabolism of Norepinephrine, Gyclic AMP and Cyclic GMP in the Atrioventricular Conducting Tissue of the Bovine Heart
}

\author{
Yoshiyuki Tamura, M.D., Shunsuke Orino, M.D., \\ Yuito AKaike, M.D., Kwan-Lih Hsu, M.D., \\ Norio Nagase, M.D., Yoshiaki Sajo, M.D., \\ Hitomi Hasur, M.D., Akira Kagoshima, M.D., \\ and Hiroyoshi MorI, M.D.
}

\section{Summary}

The distribution of norepinephrine (NE), cyclic AMP (cAMP) and cyclic GMP (cGMP) and the activities of related enzymes in the atrioventricular $(\mathrm{A}-\mathrm{V})$ conducting tissue of the bovine heart were examined. The concentration of $\mathrm{NE}$ in the atrium was about twice that in the ventricle. In the A-V conducting tissue, the concentration of NE was highest in the atrioventricular node (AVN) and lowest in the false tendon (FT), with intermediate levels in the bundle of His (HIS) and the right and left bundle branches (RLBB). The activity of monoamine oxidase (MAO) in the atrium was about 2.2 times that in the ventricle. In the $\mathrm{A}-\mathrm{V}$ conducting tissue, the activity of MAO was highest in the HIS and lowest in the FT. The activity of catechol-o-methyltransferase (COMT) in the atrium and ventricle was similar, and that in the HIS was slightly, but not significantly, higher than that in other regions of the $\mathrm{A}-\mathrm{V}$ conducting tissue. The concentration of cAMP in the ventricle was about twice that in the atrium. In the $A-V$ conducting tissue, the concentration of CAMP was higher in the AVN and FT than in the HIS and RLBB. The distribution of adenylate cyclase $(A C)$ was similar to that of NE. The phosphodiesterase (PDE) activity in the atrium and ventricle was similar. No significant difference was found in the level of PDE activity in different regions of the $\mathrm{A}-\mathrm{V}$ conducting tissue. The concentration of cGMP was slightly, but not significantly, higher in the A-V conducting tissue than in the atrium or ventricle. In the $\mathrm{A}-\mathrm{V}$ conducting tissue, the concentration of CGMP was highest in the FT and the concentrations in the HIS, RLBB and AVN were similar. These findings suggest that in the A-V conduction tissue, the regions that have the higher spontaneous pacemaker rates have higher NE content and AC activity, that is sensitivity to NE. Furthermore, the sensitivity for muscarinic cholinergic

From the Second Department of Internal Medicine, School of Medicine, University of Tokushima, Tokushima, Japan.

Address for reprints: Yoshiyuki Tamura, M.D., Second Department of Internal Medicine, School of Medicine, University of Tokushima, 2-50 Kuramoto-cho, Tokushima City 770, Japan.

Received for publication August 18, 1988.

Accepted October 11, 1988. 
stimulation is higher in the conducting tissue (especially in the FT) than in the atrium and ventricle.

\section{Additional Indexing Words:}

Norepinephrine Cyclic AMP Cyclic GMP Monoamine oxidase Catechol-o-methyltransferase Adenylate cyclase Phosphodiesterase Atrioventricular conducting tissue

Dosica OSTGANGLIONIC adrenergic nerve fibers seem to reach all parts of the heart, but the densest innervation is found in the sinus node and AVN.") The atria are also richly innervated by adrenergic fibers. In the ventricles, the adrenergic innervation is less dense and shows marked regional variation. The Purkinje system appears to be only sparsely innervated by sympathetic fibers. ${ }^{2-4)}$ The sinus node, AVN and atria also receive an abundant supply of cholinergic fibers. Although sparse cholinergic innervation is present in the ventricles, numerous cholinergic nerve fibers are present in the Purkinje system. ${ }^{\text {s) }}$

These differences in the adrenergic and cholinergic innervation of the heart, with special regard to its conducting tissue, suggest that the distribution of norepinephrinc (NE), cyclic AMP (cAMP) and cyclic GMP (cGMP) differs in various regions of the heart. Therefore, in the present study we cxamined the distribution of these substances and related enzymes in the atrioventricular $(\mathrm{A}-\mathrm{V})$ conducting tissue of the bovine heart.

\section{Materials and Methods}

Atrial, ventricular and A-V conducting tissues were isolated from bovine hearts. The animals were stunned by a blow to the head and bled to death from the common carotid arteries in a slaughterhouse. After death, the hearts were promptly removed and brought to the laboratory on ice. The epicardial and endocardial tissues from the left atrium and left ventricle and the atrioventricular conducting tissue were excised as rapidly as possible (within $1 \mathrm{~h}$ after death) in a cold room. The $\mathrm{A}-\mathrm{V}$ conducting tissue consisted of the atrioventricular node (AVN), the bundle of His (HIS), the right and left bundle branches (RLBB), and the false tendon (FT). S-AdenosylL-methionine $-{ }^{14} \mathrm{C}$ (58 mci/mmole) was obtaincd from New England Nuclcar Corporation, and L-epinephrine bitartrate from Sigma (St. Louis, MO, USA). All other compounds were obtained from Wako (Osaka, Japan) and were of the highest grade available.

Determination of $\mathcal{N} E$ :

Myocardial tissue (about $0.4 \mathrm{~g}$ ) was homogenized in $10 \mathrm{vol}$ of chilled 
$6 \%$ perchloric acid in a Polytron and the homogenate was centrifuged at $800 \mathrm{~g}$ for $20 \mathrm{~min}$ at $4^{\circ} \mathrm{C}$. The catecholamine (CA) in the tissue extract was absorbed onto aluminium oxide and oxidized with potassium ferricyanide. The concentration of the resulting trihydroxyindole was measured by highperformance liquid chromatography $\left.{ }^{6}\right)$ using a Shimadzu catecholamine analysis equipment system (Shimadzu, Kyoto, Japan).

\section{MAO assay:}

Myocardial tissue $(0.5 \mathrm{~g})$ was homogenized in $10 \mathrm{ml}$ of chilled $0.25 \mathrm{M}$ sucrose and centrifuged at $800 \mathrm{~g}$ for $10 \mathrm{~min}$ at $4^{\circ} \mathrm{C}$. The supernatant was centrifuged at $12,000 \mathrm{~g}$ for $20 \mathrm{~min}$ at $4^{\circ} \mathrm{C}$ and the precipitate was suspended in $3 \mathrm{ml}$ of $0.25 \mathrm{M}$ sucrose. The suspension was used for assay of MAO. MAO activity was assayed with m-nitrobenzylamine as the substrate ${ }^{7)}$ with a MAO assay kit from Wako (Osaka, Japan). Enzyme activity is expressed in nmoles/mg protein $/ \mathrm{h}$.

COMT assay:

COMT activity was determined by the method of Axelrod. ${ }^{8)}$ Myocardial tissue $(0.5 \mathrm{~g})$ was homogenized in $1 \mathrm{ml}$ of chilled $0.15 \mathrm{M} \mathrm{KCl}$. A volume of $0.2 \mathrm{ml}$ of homogenate was incubated with $0.1 \mathrm{ml}$ of $0.5 \mathrm{M}$ phosphate buffer, $\mathrm{pH} 7.9,0.05 \mathrm{ml} 2 \mathrm{M} \mathrm{MgCl}_{2}, 0.05 \mathrm{ml}$ L-epinephrine bitartrate $(0.5 \mu$ mole $)$ and $0.01 \mathrm{ml} \mathrm{S}$-adenosylmethionine- ${ }^{-14} \mathrm{C}(1.0 \mathrm{~m} /$ mole $)$ in a final volume of 0.5 $\mathrm{ml}$. The incubation was carried out for $1 \mathrm{~h}$ at $37^{\circ} \mathrm{C}$. The reaction was stopped with $0.5 \mathrm{ml}$ of $0.5 \mathrm{M}$ borate buffer, $\mathrm{pH} 10$ and the normetanephrine${ }^{14} \mathrm{C}$ formed was extracted into $5 \mathrm{ml}$ toluene isoamyl alcohol (3:2) by shaking for $15 \mathrm{~min}$; volumes of $3 \mathrm{ml}$ of the organic phase were transferred to counting vials and radioactivity was determined in a liquid scintillation spectrometer. Enzyme activity is expressed in pmoles of metanephrine formed $/ \mathrm{mg}$ protein $/ \mathrm{h}$.

Determinations of $c A M P$ and $c G M P$ :

Myocardial tissue (about $0.1 \mathrm{~g}$ ) was homogenized in $10 \mathrm{vol}$ of chilled $6 \%$ perchloric acid and the homogenate was centrifuged at 1,000 $\mathrm{g}$ for 10 min at $4^{\circ} \mathrm{C}$. The supernatant was neutralized with $60 \% \mathrm{KOH}$ and centrifuged at $1,000 \mathrm{~g}$ for $10 \mathrm{~min}$ at $4^{\circ} \mathrm{C}$, and the resultant supernatant was used for determinations of cAMP and cGMP. cAMP and cGMP were measured by radioimmunoassay of succinylated cAMP and cGMP as reported by Honma et $\mathrm{al}^{9)}$ using Yamasa cAMP and cGMP kits, respectively.

$A C$ assay:

$\mathrm{AC}$ activity was determined by a modification of the method of Drummond and Duncan. ${ }^{10)}$ Myocardial tissue was homogenized in $10 \mathrm{vol}$ of chilled $10 \mathrm{mM}$ Tris-HCl buffer, $\mathrm{pH} 7.5$, in a Polytron. The homogenate was strained through a coarse nylon sieve and then centrifuged at $1,000 \mathrm{~g}$ for 15 $\min$ at $4^{\circ} \mathrm{G}$. The precipitate was washed twice with the original volume of 
buffer with centrifugation. The resulting pellet was suspended in 5 vol of buffer (based on the original tissue weight) in a glass homogenizer with a loosely fitting Teflon pestle. Preparations wcre then kept on ice and used within $15 \mathrm{~min}$.

The reaction mixture (in a total volume of $0.4 \mathrm{ml}$ ) consisted of $30 \mathrm{mM}$ Tris- $\mathrm{HCl}, \mathrm{pH} \mathrm{7.5,5} \mathrm{mM} \mathrm{MgCl}{ }_{2}, 10 \mathrm{mM}$ theophylline, $1 \mathrm{mM}$ EDTA, $10 \mathrm{mM}$ phosphoenolpyruvate, $0.05 \mathrm{mg} / \mathrm{ml}$ pyruvate kinase, $2.5 \mathrm{mM}$ ATP and enzyme (usually 100 to $400 \mu \mathrm{g}$ of protein). All solutions were previously adjusted to pH 7.5. After addition of all components except enzyme, the assay tubes were equilibrated at $37^{\circ} \mathrm{C}$ for $2 \mathrm{~min}$. The reaction was started by adding suitably diluted enzyme $(0.05 \mathrm{ml})$ and incubations were carried out for 10 $\min$ at $37^{\circ} \mathrm{C}$. The reaction was stopped by placing the tubes in a boiling water bath for $3 \mathrm{~min}$. Denatured protein was removed by centrifugation at 9,000 $\mathrm{g}$ for $5 \mathrm{~min}$, and the cAMP content of the supernatant was determined by the method of Honma et al. ${ }^{9)}$ Enzyme activity is expressed in pmoles of cAMP produced $/ \mathrm{mg}$ protein $/ \mathrm{min}$.

\section{$P D E$ assay:}

The enzyme solution was prepared by the same method as for preparation of AC. PDE activity was determined by the method of Butcher and Sutherland ${ }^{11)}$ as follows: The reaction mixture contained $9.6 \mathrm{mM}$ cAMP, $24 \mathrm{mM} \mathrm{MgSO}_{4}$ and $0.16 \mathrm{M}$ Tris-HCl buffer, $\mathrm{pH} 7.5$, with a suitable dilution of the test PDE sample in a total volume of $0.8 \mathrm{ml}$. This mixture was incubated at $37^{\circ} \mathrm{C}$ for $10 \mathrm{~min}$, and then the reaction was stopped by heating the vessels at $100^{\circ} \mathrm{C}$ for $2 \mathrm{~min}$. The vessels were cooled and then incubated with $0.1 \mathrm{ml}$ of Crotalus atrox venom (1 mg of venom in $20 \mathrm{ml}$ of $0.1 \mathrm{M}$ Tris$\mathrm{HCl}$ buffer, $\mathrm{pH} 7.5$ ) at $30^{\circ} \mathrm{C}$ for $10 \mathrm{~min}$. The reaction was stopped by adding $0.1 \mathrm{ml}$ of chilled $55 \%$ trichloroacetic acid. The resulting precipitate was removed by centrifugation, and inorganic phosphate in aliquots of the supernatant were measured by the method of Fiske and Subbarow. ${ }^{12}$ Enzyme activity is expressed in $\mu$ moles of $5^{\prime}$-AMP liberated $/ \mathrm{mg}$ protein $/ \mathrm{min}$.

Protein concentration was measured by the method of Lowry et al. ${ }^{13}$ )

\section{Analysis of data:}

Data are given as means tstandard errors of means. Statistical comparisons were made by Student's t-test. The confidence level of significance for all statistical analyses was $\mathrm{p}<0.05$.

\section{Results}

1. NE concentrations

Figure 1 shows the NE concentrations of various myocardial tissues. 


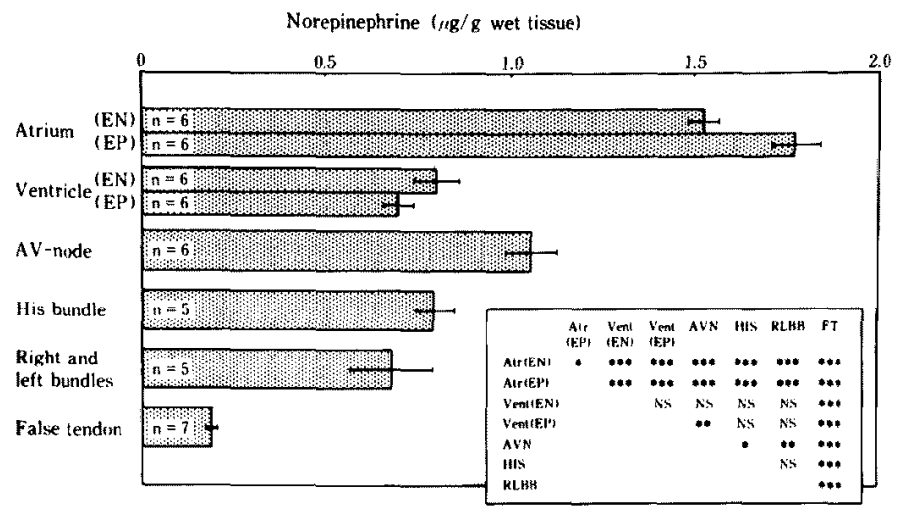

Fig. 1. Concentrations of norepinephrine in atrial, ventricular and atrioventricular conducting tissues. Columns and bars represent means and one standard error of means. $* p<0.05, * * p<0.01, * * * p<0.001$. NS = not significant; $\mathrm{n}=$ number of experiments; $\mathrm{Atr}=$ atrium; Vent $=$ ventricle; $\mathrm{AVN}=$ atrioventricular node; $\mathrm{HIS}=$ bundle of His; $\mathrm{RLBB}=$ right and left bundle branches; $\mathrm{FT}=$ false tendon; $\mathrm{EN}=$ endocardium; $\mathrm{EP}=$ epicardium.

The NE concentration of the atrial tissue was about twice that of the ventricular tissue. In the atrial tissue, the concentration in the epicardial tissue $(1.80 \pm 0.07 \mu \mathrm{g} / \mathrm{g}$ wet tissue) was higher than that in the endocardial tissue $(1.54 \pm 0.04)$, but in the ventricular tissue there was no difference in the concentrations in the epicardial tissue $(0.71 \pm 0.04)$ and the endocardial tissue $(0.81 \pm 0.06)$. In the $A-V$ conducting tissue, the NE content was highest in the AVN (1.07 \pm 0.07$)$ and lowest in the FT $(0.21 \pm 0.01)$, with intermediate levels in the HIS $(0.81 \pm 0.05)$ and the RLBB $(0.70 \pm 0.11)$.

\section{MAO and COMT activities}

The MAO activity in the atrial tissue (212.8 $\pm 24.6 \mathrm{nmoles} / \mathrm{mg}$ protein $/ \mathrm{h}$ ) was about 2.2 times that of the ventricular tissue $(95.3 \pm 10.6)$, as shown in Fig. 2. In the A-V conducting tissue, MAO activity was highest in the HIS $(89.8 \pm 3.9)$ and lowest in the FT $(61.6 \pm 2.8)$, with intermediate activities in

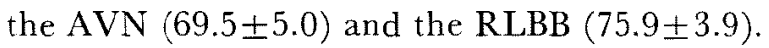

COMT activity of the atrial tissue $(211.3 \pm 26.2)$ was slightly, but not significantly, higher than that of the ventricular tissue (171.7 \pm 23.1$)$, as shown in Fig. 3. In the A-V conducting tissue, the COMT activity in the HIS (325.5 \pm 87.9$)$ was slightly, but not significantly, higher than those in the other parts.

3. cAMP concentrations

Figure 4 shows the cAMP concentrations of various myocardial tissues. The cAMP concentration of the ventricular tissue was about twice that of the 


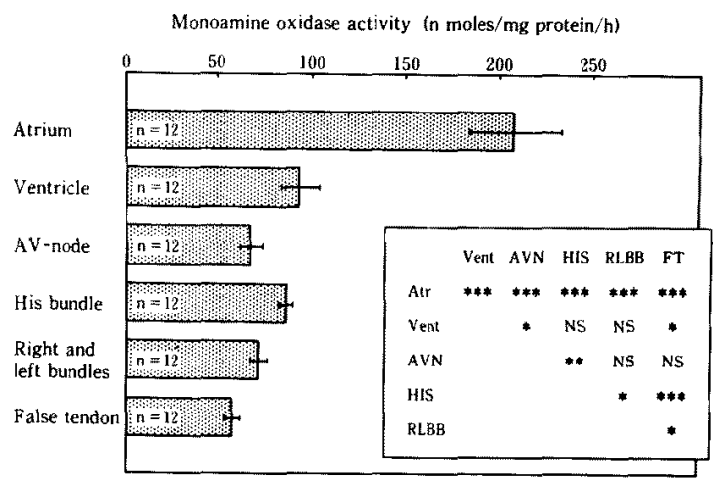

Fig. 2. Monoamine oxidase activities in atrial, ventricular and atrioventricular conducting tissues. Columns and bars represent means and one standard error of means. * $\mathrm{p}<0.05, * * \mathrm{p}<0.01, * * * \mathrm{p}<0.001 . \quad$ NS $=$ not significant; $\mathrm{n}=$ number of experiments. Other abbreviations are as for Fig. 1 .

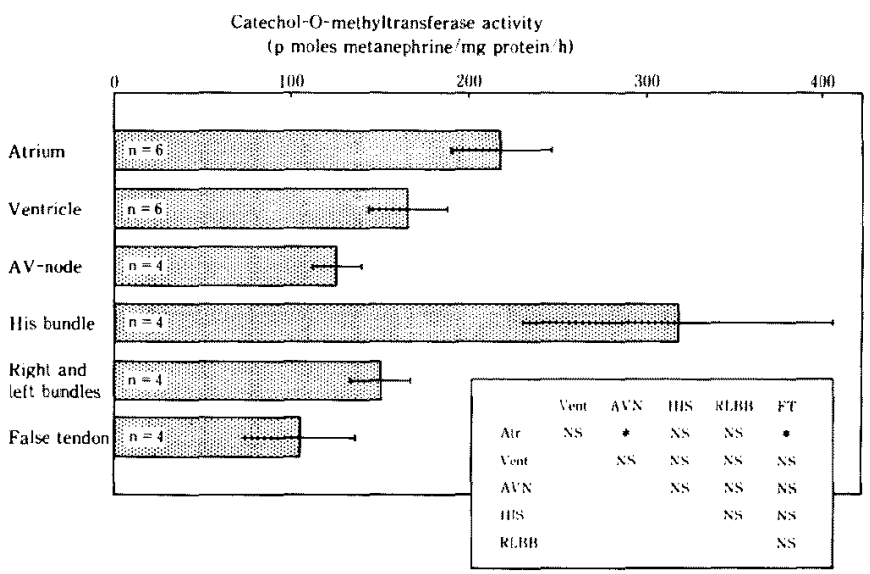

Fig. 3. Gatechol-o-methyltransferase activities in atrial, ventricular and atrioventricular conducting tissues. Columns and bars represent means and one standard error of means. $* p<0.05$. NS = not significant; $n=$ number of experiments. Other abbreviations are as for Fig. 1.

atrial tissue. There were no differences between the concentrations in the endocardial tissue $(1.89 \pm 0.14 \mathrm{nmoles} / \mathrm{g}$ wet tissue) and the epicardial tissue $(1.77 \pm 0.12)$ of the atrium or between those in the endocardial tissue $(3.45 \pm$ $0.54)$ and the epicardial tissue $(3.21 \pm 0.25)$ of the ventricle. In the A-V conducting tissue, the cAMP concentrations in the AVN $(0.59 \pm 0.05)$ and the FT $(0.71 \pm 0.10)$ were higher than those in the HIS $(0.43 \pm 0.03)$ and RLBB $(0.46 \pm 0.04)$. 


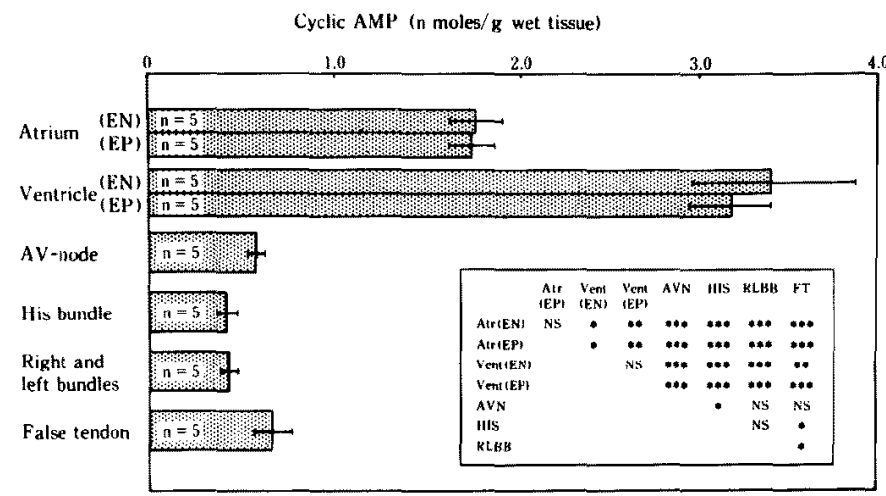

Fig. 4. Concentrations of cyclic AMP in atrial, ventricular and atrioventricular conducting tissues. Columns and bars represent means and one standard error of means. $* \mathrm{p}<0.05, * * \mathrm{p}<0.01, * * * \mathrm{p}<0.001$. NS $=$ not significant; $\mathrm{n}=$ number of experiments. Other abbreviations are as for Fig. 1 .

4. AG and PDE activities

The AC activities in the endocardial tissue (19.44 \pm 2.24 pmoles cAMP/ $\mathrm{mg}$ protein $/ \mathrm{min})$, and the epicardial tissue $(17.28 \pm 0.84)$ of the atrium were about 3 times those in the endocardial tissue $(6.07 \pm 1.17)$ and the epicardial tissuc $(6.78 \pm 1.31)$ of the ventricle, as shown in Fig. 5. In the A-V conducting tissue, the AC activity was highest in the AVN (13.26 \pm 2.39 ), lowest in the FT $(1.33 \pm 0.28)$ and intermediate in the HIS (5.20 \pm 0.59$)$ and the RLBB $(4.97 \pm 1.85)$.

The PDE activities in the atrial tissue (endocardial tissue, $11.91 \pm 2.35$ $\mu$ moles AMP/mg protein $/ \mathrm{min}$; epicardial tissue, $9.87 \pm 1.75$ ) and the ventricular tissue (endocardial tissue, $12.00 \pm 1.56$; epicardial tissue, $11.85 \pm 1.12$ ) were similar, as shown in Fig. 6. The PDE activities in each portion of the A-V conducting tissue were significantly lower than those of the atrial and ventricular tissues. In the A-V conducting tissue, the PDE activity of the AVN $(1.35 \pm 0.44)$ was slightly, but not significantly, lower than those of the HIS $(2.22 \pm 0.69), \operatorname{RLBB}(4.13 \pm 0.90)$ and FT $(1.91 \pm 0.29)$.

\section{5. cGMP concentrations}

Figure 7 shows the cGMP concentrations of various myocardial tissues. In the atrial tissue, the concentration of the epicardial tissue $(10.77 \pm 1.41$ pmoles/g wet tissue) was higher than that of the endocardial tissue (5.54 上 0.30 ). In the ventricular tissue there was no difference in the concentrations in the endocardial tissue $(7.23 \pm 0.24)$ and epicardial tissue $(8.21 \pm 1.19)$. In the $\mathrm{A}-\mathrm{V}$ conducting tissue, the cGMP concentration was highest in the FT

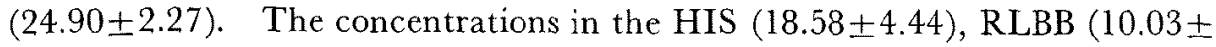




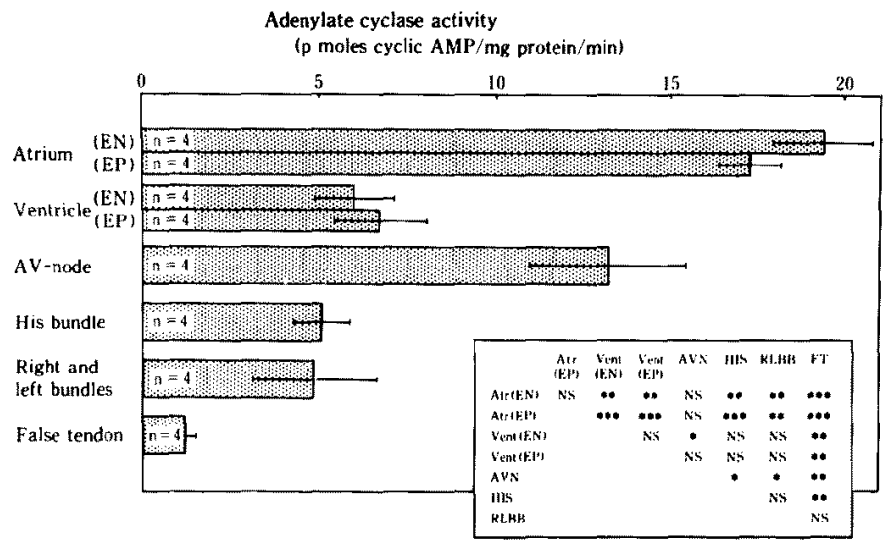

Fig. 5. Adenylate cyclase activities in atrial, ventricular and atrioventricular conducting tissues. Columns and bars represent means and one standard error of means. $* \mathrm{p}<0.05, * * \mathrm{p}<0.01, * * * \mathrm{p}<0.001$. NS $=$ not significant; $\mathrm{n}=$ number of experiments. Other abbreviations are as for Fig. 1 .

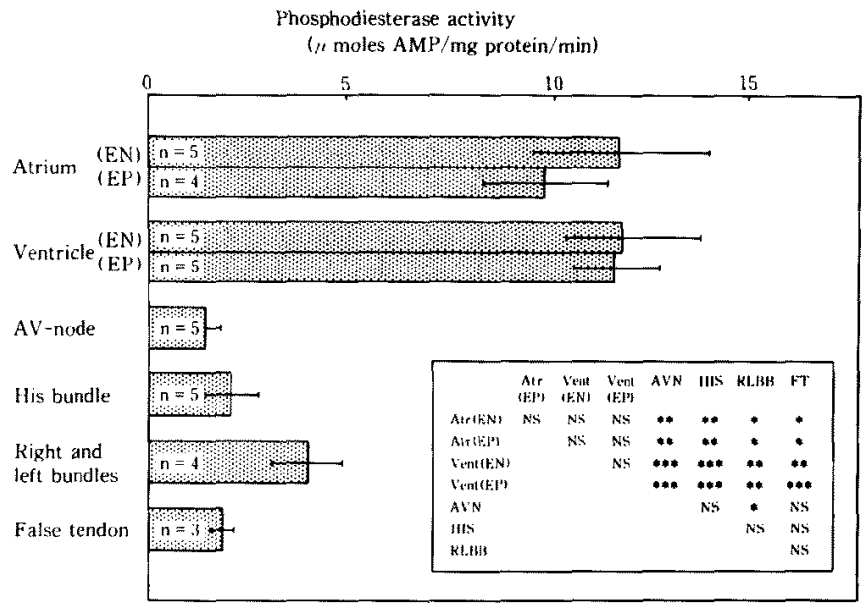

Fig. 6. Phosphodiesterase activities in atrial, ventricular and atrioventricular conducting tissues. Columns and bars represent means and one standard error of means. ${ }^{*} \mathrm{p}<0.05, * * \mathrm{p}<0.01, * * * \mathrm{p}<0.001$. NS = not significant; $n=$ number of experiments. Other abbreviations are as for Fig. 1 .

$1.35)$ and AVN (8.98 1.44$)$ were not significantly different.

\section{Discussion}

Catecholamines are widely distributed in animals, especially in nerve cells. NE is mainly localized in peripheral postganglionic sympathetic nerves. 


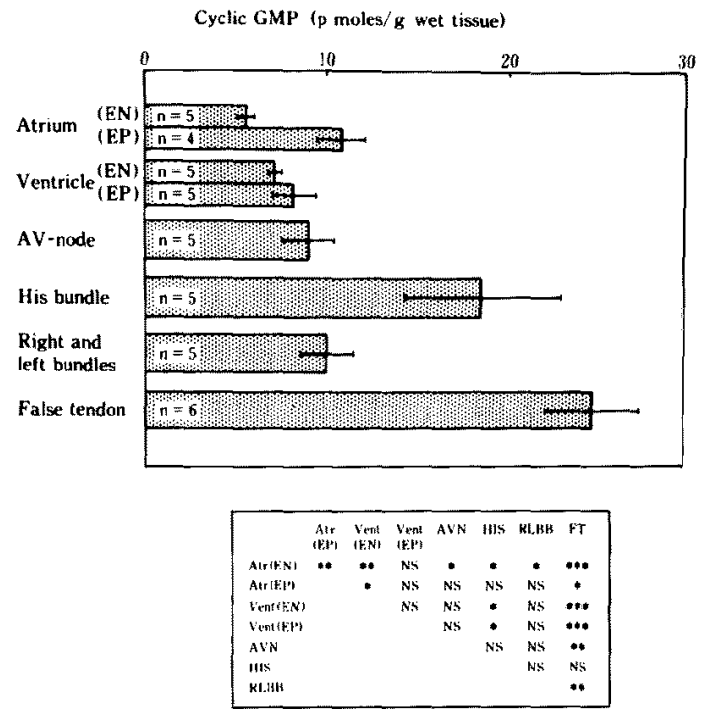

Fig. 7. Concentrations of cyclic GMP in atrial, ventricular and atrioventricular conducting tissues. Columns and bars represent means and one standard error of means. ${ }^{*} \mathrm{p}<0.05, * * \mathrm{p}<0.01, * * * \mathrm{p}<0.001 . \quad \mathrm{NS}=$ not significant; $n=$ number of experiments. Other abbreviations are as for Fig. 1 .

The NE concentration in some sympathetic ganglia is as high as $100 \mu \mathrm{g} / \mathrm{g}$, while in sympathetically innervated tissues its concentration ranges from 0.1 to $2 \mu \mathrm{g} / \mathrm{g} .{ }^{14), 15)}$

In the present study, the $N E$ concentrations in various regions of the heart were found to range from 0.21 to $1.80 \mu \mathrm{g} / \mathrm{g}$ wet tissue. In the heart, the $\mathrm{NE}$ concentration was highest in the atrium (especially the epicardial tissue). In the A-V conducting tissue, the NE concentration was highest in the AVN and lowest in the FT, with intermediate concentrations in the HIS and RLBB. The NE distribution seemed to be almost consistent with the density of postganglionic adrenergic nerve fibers in the heart. ${ }^{1)}$ The NE concentration in the AVN was lower than that in the atrium, but because the conducting tissue of bovine heart contains more connective tissue (about 60\%) than ordinary myocardial tissue (less than 10\%), ${ }^{16}$ ) the actual NE concentrations in the AVN and other regions of the $A-V$ conducting tissue are probably higher than the observed values.

The activities of MAO and COMT were higher in the atrium than in the ventricle. In the $\mathrm{A}-\mathrm{V}$ conducting tissue, the activity of $\mathrm{MAO}$ was in the order HIS $>A V N$ and RLBB $>$ FT. The activity of COMT in the HIS tended to be high in the $A-V$ conducting tissue. These results suggest that the metabolism of NE is more rapid in the atrium than in the ventricle and 
that in the A-V conducting tissue it is most rapid in the HIS.

$\mathrm{NE}$ affects the heart by interaction with $\beta$-receptors. Stimulation of $\beta$ adrenergic receptors results in activation of $\mathrm{AC}$ via a regulatory coupling protcin that binds guanine nucleotides. ${ }^{17), 18)}$ The activation of AC leads to an increase in intracellular cAMP, which mediates many of the physiologic effects of stimulation of $\beta$ adrenergic receptors by NE.19),20) Probably by action on cAMP-dependent protein kinases, cAMP triggers phosphorylation reactions of proteins that directly or indirectly increase the transmembranal influx of $\mathrm{Ca}^{2+}$; cAMP may affect fluxes of other ions as well, accounting for changes in the electrophysiological behavior of myocardial cells. ${ }^{1)}$

Previously ${ }^{21)}$ we reported that the concentration of CAMP and the activity of AC were higher in the AVN than in the HIS and RLBB. In the present study, we examined the distribution of CAMP, AC and PDE in the atrium, ventricle and $\mathrm{A}-\mathrm{V}$ conducting tissue consisting of the AVN, HIS, $\mathrm{RLBB}$ and FT. The activity of $\mathrm{AC}$ was higher in the atrium than in the ventricle, and in the $A-V$ conducting tissue its activity was in the order AVN> HIS and RLBB $>$ FT. These findings show that the distribution of AC activity was consistent with that of NE. Therefore, in the A-V conducting tissue, the regions that have the higher spontaneous pacemaker rates have higher NE contents and AG activity, that is sensitivity to NE.

The cAMP concentration was found to be lower in the atrium than in the ventricle. In the A-V conducting tissue, the cAMP concentrations in the AVN and FT were higher than those in the HIS and RLBB. There was no significant difference in the PDE activity in the atrium and ventricle. The PDE activity was similar in the various regions of the A-V conducting tissue. Thus, disparity was found between the AC activity and the cAMP concentration. Further studies of additional factors regulating the AC activity and ATP level are necessary to explain this disparity.

Many studies in a variety of tissues have shown that activation of muscarinic receptors leads to an increase in the tissue concentration of cGMP. ${ }^{22}$ ) Thus under appropriate conditions, possibly related to the concentration of $\mathrm{Ca}^{2+}$ in the extracellular medium, activation of muscarinic receptors certainly increases the myocardial tissue cGMP level. The present study showed that the cGMP concentration in the A-V conducting tissue tended to be higher than those in the atrium and ventricle. In the A-V conducting tissue, the cGMP concentration was highest in the FT. These results suggest that the sensitivity to muscarinic cholinergic stimulation is higher in the conducting tissue than in the atrium and ventricle and that in the $A-V$ conducting tissue it is highest in the FT. However, the physiological significance of this elcvation in the cGMP level is controversial. ${ }^{23)}$ 
The present study demonstrated the heterogeneous distributions of $\mathrm{NE}$, cAMP, cGMP and the activities of related enzymes in the A-V conducting tissue. Studies of the distribution and physiological properties of adrenergic and muscarinic receptors arc in progress.

\section{REFERENCES}

1. Wikberg JES, Lefkowitz RJ: Adrenergic receptors in the heart: Pre- and postsynaptic mechanisms, in Nervous Control of Cardiovascular Function, ed by Randall WC, Oxford University Press, New York, p 95, 1984

2. Dahlstrom A, Fuxe K, Mya-Tu M, Zetterstrom BEM: Observations on adrenergic innervation of dog heart. Am J Physiol 209: 689, 1965

3. Shindler R, Harakal C, Sevy RW: Catecholamine content of the sinoatrial node and common right atrial tissue. Proc Soc Exp Biol Med 128: 798,1968

4. Thaemert JC: Atrioventricular node innervation in ultrastructural three dimensions. Am J Anat 128: 239, 1970

5. Kent KM, Epstein SE, Cooper T, Jacobowitz DM: Cholinergic innervation of the canine and human ventricular conducting system. Anatomic and electrophysiologic correlations. Circulation 50: 948,1974

6. Mori $\mathrm{K}$ : High-speed ion-exchange chromatographic assay in the picomole range of biogenic amines. Ind Health 12: 171, 1974

7. Ito $\mathrm{K}$, Yamamoto $\mathrm{Y}$, Tachibana M, Nakata F, Matsumoto $\mathrm{K}$ : Monoamine oxidase. Nihon Rinsho 43 (suppl): 196, 1985 (in Japanese)

8. Axelrod J: Catechol-o-methyltransferase from rat liver. in Methods in Enzymology, vol 5, ed by Colowick SP, Kaplan NO, Academic Press, New York, p 748, 1962

9. Honma M, Satoh T, Takezawa J, Ui M: An ultrasensitive method for the simultaneous determination of cyclic AMP and cyclic GMP in small-volume samples from blood and tissue. Biochem Mcd 18: 257, 1977

10. Drummond GI, Duncan L: Adenyl cyclase in cardiac tissue. J Biol Chem 245: 976,1970

11. Butcher RW, Sutherland EW: Adenosine $3^{\prime}, 5^{\prime}$-phosphate in biological materials. 1. Purification and properties of cyclic 3',5'nucleotide phosphodiestcrase and use of this enzyme to characterize adenosine 3',5'phosphate in human urine. J Biol Chem 237: 1244, 1962

12. Fiske CR, Subbarow Y: The colorimetric determination of phosphorus. J Biol Chem 66 : 375,1925

13. Lowry $\mathrm{OH}$, Rosebrough NJ, Farr AL, Randall RJ: Protein measurement with the folin phenol reagent. J Biol Chem 193: 265, 1951

14. von Euler US: Noradrenaline: Chemistry, Physiology, Pharmacology and Clinical Aspects, Charles C Thomas Pub, Springfield, 1956

15. Anton AH, Sayre OF: A study of the factors affecting the aluminium oxide-trihydroxyindole procedure for the analysis of catechalamines. J Pharmacol Exp Ther 138: 360, 1962

16. Higuchi M, Nishi $\mathrm{K}$, Takenaka F: A comparison of enzyme activity for energy production in myocardium and conduction system. Jpn Heart J 20:667, 1979

17. Ross EM, Gilman AG: Biochemical properties of hormone-sensitive adenylate cyclase. Ann Rev Biochem 49:533, 1980

18. Stiles GL, Caron MG, Lefkowitz RJ: $\beta$-Adrenergic receptors: Biochemical mechanisms of physiological regulation. Physiol Rev 64: 661, 1984

19. Kukovetz WR, Poch G, Wurm A: Quantitative relations between cyclic AMP and contraction as affected by stimulators of adenylate cyclase and inhibitors of phosphodiesterase. Adv Cyclic Nucleotide Res 5: 395, 1975

20. Tsien RW: Cyclic AMP and contractile activity in the heart, Adv Cyclic Nucleotide Res 
8: 363,1977

21. Tamura Y, Saito M, Matsumura K, Saito K, Kudo T, Ishimaru K, Niki T, Mori H: Cyclic adenosine $3^{\prime}, 5^{\prime}$-monophosphate, adenyl cyclase and phosphodiesterase in the conduction system of bovine heart. Jpn Circ J 47: 351, 1983

22. Goldberg ND, Haddok MK: Cyclic GMP metabolism and involvement in biological regulation. Ann Rev Biochem 46: 823, 1977

23. Linden J, Brooker G: The questionable role of cyclic guanosine $3^{\prime}, 5^{\prime}$-monophosphate in heart. Biochem Pharmacol 28: 3351, 1979 